Article

\title{
Pre- and Post-Harvest Practices of Urban Leafy Green Vegetable Farmers in Accra, Ghana and Their Association with Microbial Quality of Vegetables Produced
}

\author{
Joycelyn K. Quansah ${ }^{1,2}$, Cesar L. Escalante ${ }^{3}{ }^{\circledR}$, Angela P.-H. Kunadu ${ }^{2}$, Firibu K. Saalia ${ }^{2}$ and \\ Jinru Chen ${ }^{1, *}$ \\ 1 Department of Food Science and Technology, The University of Georgia, Griffin, GA 30223, USA; \\ joyquansah@ug.edu.gh \\ 2 Department of Nutrition and Food Science, University of Ghana, Legon P.O. Box LG 134, Ghana; \\ AParry-Hanson@ug.edu.gh (A.P.-H.K.); FSaalia@ug.edu.gh (F.K.S.) \\ 3 Department of Agricultural and Applied Economics, The University of Georgia, Athens, GA 30602, USA; \\ cescalan@uga.edu \\ * Correspondence: jchen@uga.edu
}

Received: 25 November 2019; Accepted: 13 January 2020; Published: 15 January 2020

\begin{abstract}
Vegetable farming is the most practiced urban agriculture in Ghana. A previous study of our laboratory revealed poor microbial quality of, and presence of Salmonella on, leafy green vegetables grown or sold in Accra, Ghana. The aims of this study were to determine agricultural practices of urban vegetable farmers and the association between agricultural practices and microbial safety of vegetables produced. A survey was conducted among 102 farmers from 12 farming areas who produced exotic and indigenous leafy greens in Accra, Ghana to identify their farming practices. It was observed that water from waste drains pumped into shallow wells was used for irrigation by $70 \%$ of the farmers. Incompletely composted manure was commonly used (99\%) in farming. Vegetables were usually harvested using bare hands (96\%) and knives (73\%) and transported mainly in sacks (94\%) to market centers under non-refrigerated conditions. Over $60 \%$ of the farmers disagreed that the use of polluted irrigation water can contaminate vegetables or make consumers sick. According to the seemingly unrelated regression model, farmers with no formal education and less food safety knowledge and had been planting on their current farmlands for several years were likely to produced vegetables with higher fecal coliform and Enterococcus sp. counts compared to other farmers. Vegetables cultivated by farmers who disagreed that the use of contaminated water can make consumers sick were associated with the production of vegetables with high fecal coliform and Enterococcus sp. counts. Education and improved agricultural and post-harvest handling practices should be encouraged among vegetable producers in the area to improve food safety.
\end{abstract}

Keywords: leafy green vegetable; vegetable farming practice; vegetable safety; manure; irrigation

\section{Introduction}

Urban and peri-urban agriculture (UPA) includes agricultural activities such as production, processing and distribution occurring within, and around cities for home consumption and/or for the urban market. UPA includes the production of crops, poultry, livestock, fisheries and forestry $[1,2]$. Increased UPA activities have been attributed to increasing urbanization in many countries around the world. It is a significant source of fresh and perishable food, income and food security [1,3-6]. 
Vegetable farming is the most prevalent urban agricultural activity in Ghana [7]. The UPA vegetable farming is usually implemented as: year-round production of vegetables mainly for commercial purposes, peri-urban farming where vegetables are grown on a seasonal basis for commercial purposes, and backyard farming where vegetables are cultivated usually for home consumption or commercial purposes [8]. Ghanaian vegetable farmers plant exotic and indigenous vegetables in urban and peri-urban farms [7]. Vegetable farms are usually situated close to various sources of water to meet year-round irrigation and production demands [8]. Fertilizers and pesticides are used in vegetable cultivation to maintain soil fertility and control pest and diseases. Farming activities are usually labor intensive land preparation, weeding and irrigation. At maturity, vegetables are harvested and usually bought by wholesalers and retailers who transport them to markets [9].

Low microbial quality of leafy green vegetables from urban and peri-urban farms in Ghana has been reported by some early studies [10-12]. Our recent study revealed poor microbial quality of, and presence of Salmonella sp. on, leafy green vegetables grown or sold in Accra, Ghana [13]. The aims of this study were to determine agricultural practices of urban vegetable farmers and the association between agricultural practices and microbial quality of leafy green vegetables produced in the area.

\section{Materials and Methods}

\subsection{Survey}

Vegetable farms in and around the Accra Metropolis district of Ghana growing exotic (Lactuca sativa L. var crispa (lettuce) and Brassica oleracea L. var. capitata f. alba (cabbage)) and indigenous (Amaranthus sp. (African spinach), Solanum macrocarpon L. Gilo (African eggplant leaves), Hibiscus sabdariffa L. (roselle leaves) and Corchorus olitorius L. (jute leaves)) leafy green vegetables were identified. Information about the geographic location of the farms can be found in a previous publication of our laboratory [13].

Vegetable farmers who were willing to participate were included in the study during the period from March 2016 to March 2017. Semi structured questionnaires were administered to 102 farmers from 12 farming areas to obtain information on farming and postharvest practices associated with leafy green vegetable cultivation. The University of Georgia Institutional review board declared that the survey did not require ethical clearance because it is not about the farmers but about their farming operations.

\subsection{Statistical Analysis}

Leafy green vegetables were subsequently collected from the farmers that participated in the study, and fecal coliform and Enterococcus sp. counts on collected vegetable samples were determined and published separately [13]. Seemingly unrelated regression (SUR) model of statistical data analysis (STATA) Software (StateCorp LP, College Station, TX USA) was used in this study to correlate the fecal coliform or Enterococcus sp. counts to vegetable farming and postharvest practices reported by the farmers in their responses to circulated questionnaires. The basic SUR system assumes that for each individual observation there are cross-sectional units, each with its own linear regression model [14].

The SUREG procedure in STATA was used because it is an asymptotically efficient, feasible generalized least-squares algorithm. The resulting generalized least square estimator, designed to address heteroscedastic and auto-correlated disturbances was used [14]. Our model includes two equations, one for each of the two measures of possible contaminants as the dependent variable. Explanatory variables include the demographic attributes of farmers, enterprise dummy variables capturing types of leafy green vegetables planted, farming, irrigation and post-harvest practices employed by the farmers, extension or training services received by the farmer respondents and food safety knowledge.

This system of equations is estimated for a general model based on all farm observations in the sample. The SUR approach to this empirical issue is justified by the results of the Breusch and Pagan (BP) test of independence conducted on the different models. The BP test yielded a chi-square test 
statistic with significant $p$-value that refutes the BP test's null hypothesis of independence. There is a presence of contemporaneous correlation between residuals of equations in the system, thus justifying the use of the SUR estimation technique.

\section{Results}

Most people engaged in leafy green vegetable farming in Accra, Ghana were males (98.0\%; Table 1). Approximately $70.0 \%$ of the farmers were aged between 18 and 45 years; $20.6 \%$ were between the ages of 46 and 60 years while $9.8 \%$ were older than 60 years. About $50.0 \%$ of the farmers had no formal education while none had tertiary education. However, some farmers had education up to the primary $(16.7 \%)$, junior high school (20.6\%) and senior high school (13.7\%) levels.

Table 1. Demography of surveyed vegetable farmers in Accra, Ghana.

\begin{tabular}{ll}
\hline \multicolumn{1}{c}{ Survey Attributes } & Percentage (\%) \\
\hline Farming areas where participating farmers were from & \\
Farming area 1 & 19.6 \\
Farming area 2 & 2.9 \\
Farming area 3 & 5.9 \\
Farming area 4 & 10.8 \\
Farming area 5 & 31.4 \\
Farming area 6 & 7.8 \\
Farming area 7 & 5.9 \\
Farming area 8 & 2.0 \\
Farming area 9 & 2.9 \\
Farming area 10 & 5.9 \\
Farming area 11 & 2.9 \\
Farming area 12 & 2.0 \\
Age range (years) of participating farmers & \\
18-30 & 24.5 \\
31-45 & 45.1 \\
46-60 & 20.6 \\
>60 & 9.8 \\
Gender of participating farmers & \\
Male & 98.0 \\
Female & 2.0 \\
Level of education of participating farmers & \\
None & 49.0 \\
Primary school & 16.7 \\
Junior high school & 20.6 \\
Senior high school & 13.7 \\
Tertiary & 0.0 \\
\hline
\end{tabular}

The total number of respondents was 102 .

Vegetable farming in urban areas of Accra, Ghana were small-scale, with $70.6 \%$ of the farmers having farms with sizes less than 0.4 ha; $25.5 \%$ had farm sizes between 0.4 and 1.2 ha and $3.9 \%$ had farm sizes greater than 1.2 ha (Table 2). Approximately $57.0 \%$ of the farmers worked alone on their farms while $41.2 \%$ of the farms had two to four farm workers. Some of the farmers had been cultivating vegetables for less than 10 years (29.4\%), 11-20 years (34.3\%), 21-30 years (25.5\%) and 31-50 years $(9.8 \%)$. Most farmers (57.0\%) had been planting on their current lands for 10 years or less. Few farmers $(4.0 \%)$ had been planting on the same lands for 31 years or longer, and one of the farmers had been planting vegetables on the same land for over 50 years. 
Table 2. Characteristics of participating vegetables farms in Accra, Ghana.

\begin{tabular}{|c|c|}
\hline Survey Attributes & Percentage $(\%)$ \\
\hline \multicolumn{2}{|l|}{ Farm size (ha) } \\
\hline 0 to 0.40 & 70.6 \\
\hline 0.41 to 0.80 & 13.7 \\
\hline 0.81 to 1.20 & 11.8 \\
\hline 1.21 to 1.60 & 2.9 \\
\hline$>1.60$ & 1.0 \\
\hline \multicolumn{2}{|l|}{ Number of farm workers } \\
\hline 1 & 56.9 \\
\hline 2 & 14.7 \\
\hline 3 & 16.7 \\
\hline 4 & 9.8 \\
\hline 5 & 1.0 \\
\hline 6 & 0.0 \\
\hline 7 & 1.0 \\
\hline \multicolumn{2}{|l|}{ Main vegetables cultivated } \\
\hline Amaranthus sp. & 46.1 \\
\hline B. oleracea & 84.3 \\
\hline C. olitorius & 35.3 \\
\hline H. sabdariffa & 25.5 \\
\hline L. sativa & 100.0 \\
\hline S. macrocarpon & 28.4 \\
\hline \multicolumn{2}{|c|}{ Reason influencing type of vegetable cultivated } \\
\hline Expertise & 13.7 \\
\hline Market demands & 73.5 \\
\hline Soil conditions & 20.6 \\
\hline Weather conditions & 50.1 \\
\hline \multicolumn{2}{|l|}{ Reasons for practicing crop rotation } \\
\hline Changes in weather conditions & 5.9 \\
\hline Low soil fertility & 58.8 \\
\hline Minimize spread of pest and disease & 44.1 \\
\hline \multicolumn{2}{|l|}{ Other vegetables cultivated by farmers } \\
\hline Beet root & 8.8 \\
\hline Carrot & 9.8 \\
\hline Cauliflower & 30.4 \\
\hline Chinese cabbage & 6.9 \\
\hline Okra & 5.9 \\
\hline Onion & 16.7 \\
\hline \multicolumn{2}{|l|}{ Vegetable cultivation experience (years) } \\
\hline 1 to 5 & 12.8 \\
\hline 6 to 10 & 16.7 \\
\hline 11 to 15 & 18.6 \\
\hline 16 to 20 & 15.7 \\
\hline 21 to 25 & 11.8 \\
\hline 26 to 30 & 13.7 \\
\hline 31 to 40 & 7.8 \\
\hline 41 to 50 & 2.0 \\
\hline$>50$ & 1.0 \\
\hline \multicolumn{2}{|l|}{ Planting on current farmland (years) } \\
\hline 1 to 5 & 34.3 \\
\hline 6 to 10 & 22.5 \\
\hline 11 to 15 & 14.7 \\
\hline 16 to 20 & 9.8 \\
\hline 21 to 25 & 4.9 \\
\hline 26 to 30 & 9.8 \\
\hline 31 to 40 & 2.9 \\
\hline 41 to 50 & 1.0 \\
\hline$>50$ & 0.0 \\
\hline
\end{tabular}

The total number of respondents was 102. 
The farmers in this study cultivated exotic leafy green vegetables more than the indigenous ones. All the farmers cultivated L. sativa, while $84.3 \%$ cultivated B. oleracea (Table 2). Among the indigenous Ghanaian leafy green vegetables, Amaranthus sp., C. olitorius, H. sabdariffa and S. macrocarpon were cultivated by $46.1 \%, 35.3 \%, 25.5 \%$ and $28.4 \%$ of the farmers, respectively. Market demand $(73.5 \%)$ and weather conditions (50.0\%) were the major factors influencing the type of vegetables cultivated. Soil condition (20.6\%) and expertise (13.7\%) were other factors that the farmers considered in deciding the type of vegetables to plant. The farmers rotated the types of vegetables they cultivated due to soil fertility $(58.8 \%)$, pests and diseases $(44.1 \%)$, and changes in weather conditions $(5.9 \%)$. Other vegetables cultivated by the farmers included cauliflower (Brassica oleracea var. botrytis), onions (Allium cepa), carrot (D. carota var sativus), beet root (Beta vulgaris), Chinese cabbage (Brassica rapa var chinensis) and okra (Abelmoschus esculentus). More farmers planted B. oleracea once or twice a year and L. sativa five to six times a year (Table 3). Indigenous leafy vegetables were mostly cultivated once or twice a year, but some were planted as often as seven to eight times a year.

Table 3. Planting practices of participating vegetable farms in Accra, Ghana.

\begin{tabular}{|c|c|c|c|c|c|c|}
\hline \multirow{2}{*}{ Survey Attributes } & \multicolumn{6}{|c|}{ Percentage (\%) of Farmers Planting } \\
\hline & Amaranthus sp. & B. oleracea & C. olitorius & H. sabdariffa & L. sativa & S. macrocarpon \\
\hline \multicolumn{7}{|l|}{$\begin{array}{c}\text { How often } \\
\text { vegetables were } \\
\text { planted in a year }\end{array}$} \\
\hline $1-2$ & 55.9 & 46.1 & 62.8 & 73.5 & 2.0 & 69.6 \\
\hline $3-4$ & 5.9 & 30.4 & 6.9 & 6.9 & 10.8 & 2.9 \\
\hline $5-6$ & 9.8 & 2.9 & 5.9 & 1.0 & 44.1 & 6.9 \\
\hline $7-8$ & 22.5 & 0.0 & 20.6 & 13.7 & 19.6 & 16.7 \\
\hline $9-10$ & 0.0 & 0.0 & 0.0 & 0.0 & 6.9 & 0.0 \\
\hline $11-12$ & 2.0 & 0.0 & 2.0 & 1.0 & 11.8 & 1.0 \\
\hline $13-14$ & 0.0 & 0.0 & 0.0 & 0.0 & 1.0 & 0.0 \\
\hline \multicolumn{7}{|l|}{$\begin{array}{l}\text { How often pesticides } \\
\text { were applied in a } \\
\text { growing cycle }\end{array}$} \\
\hline 1 & 15.7 & 2.0 & 13.7 & 7.8 & 6.9 & 11.8 \\
\hline 2 & 9.8 & 2.9 & 6.9 & 4.9 & 11.8 & 5.9 \\
\hline 3 & 12.7 & 5.9 & 7.8 & 5.9 & 14.7 & 6.9 \\
\hline 4 & 0.0 & 3.9 & 1.0 & 1.0 & 30.4 & 0.0 \\
\hline 5 & 0.0 & 20.6 & 0.0 & 0.0 & 3.9 & 0.0 \\
\hline 6 & 0.0 & 2.9 & 0.0 & 0.0 & 5.9 & 0.0 \\
\hline 7 & 0.0 & 0.0 & 0.0 & 0.0 & 20.6 & 0.0 \\
\hline 8 & 0.0 & 36.3 & 0.0 & 0.0 & 2.0 & 0.0 \\
\hline 9 & 0.0 & 0.0 & 0.0 & 0.0 & 0.0 & 0.0 \\
\hline 10 & 0.0 & 10.8 & 0.0 & 0.0 & 0.0 & 0.0 \\
\hline 1 & 11.8 & 46.1 & 7.8 & 8.8 & 74.5 & 7.8 \\
\hline 2 & 3.9 & 2.0 & 3.9 & 5.9 & 23.5 & 1.0 \\
\hline 3 & 0.0 & 8.8 & 0.0 & 0.0 & 2.0 & 0.0 \\
\hline 4 & 0.0 & 2.9 & 0.0 & 0.0 & 0.0 & 0.0 \\
\hline
\end{tabular}

The total number of respondents was 102 .

Although all the farmers depended on rainfall, they also employed surface water to irrigate the vegetables. Water from waste drains pumped into shallow wells $(69.6 \%)$ was the most common source of irrigation water (Table 4$)$. Availability of water (98.0\%) and distance to water source $(65.7 \%)$ were the major factors influencing the choice of water used for irrigation. Cleanliness of the water $(3.9 \%)$ and cost of water $(6.9 \%)$ were the factors least considered in choosing irrigation water for vegetable production. Watering can $(70.6 \%)$, small motorized pumps connected to sprinkler $(60.8 \%)$ and water hose $(4.9 \%)$ were the appliances used for irrigating vegetables. Most of the farmers irrigated their vegetables three to four times $(49.0 \%)$ or seven to eight times (34\%) weekly. 
Table 4. Irrigation, fertilizer and pesticide use practices of participating vegetable farms in Accra, Ghana.

\begin{tabular}{|c|c|}
\hline Survey Attributes & Percentage $(\%)$ \\
\hline \multicolumn{2}{|l|}{ Source of irrigation water } \\
\hline Bore hole & 2.0 \\
\hline Pipe & 7.8 \\
\hline Pond & 2.9 \\
\hline River & 19.6 \\
\hline Stream & 2.0 \\
\hline Waste drains & 69.6 \\
\hline \multicolumn{2}{|l|}{ Factors influencing choice of irrigation water } \\
\hline Availability & 98.0 \\
\hline Cleanliness of water & 3.9 \\
\hline Cost & 6.9 \\
\hline Distance to water source & 65.7 \\
\hline \multicolumn{2}{|l|}{ Appliance used in irrigation } \\
\hline Small motorized pumps with sprinkler & 60.8 \\
\hline Watering can 1 & 70.6 \\
\hline Water hose & 4.9 \\
\hline \multicolumn{2}{|l|}{ How often vegetables were irrigated per week (times) } \\
\hline 1 to 2 & 3.9 \\
\hline 3 to 4 & 49.0 \\
\hline 5 to 6 & 2.9 \\
\hline 7 to 8 & 34.3 \\
\hline 9 to 10 & 0.0 \\
\hline$>10$ & 8.8 \\
\hline \multicolumn{2}{|l|}{ Synthetic fertilizers used } \\
\hline Ammonia or urea & 48.0 \\
\hline NPK (Nitrogen-phosphorus-potassium) & 72.5 \\
\hline None & 1.0 \\
\hline \multicolumn{2}{|l|}{ Organic fertilizers used } \\
\hline Cow manure & 8.8 \\
\hline Poultry manure & 99.0 \\
\hline None & 1.0 \\
\hline \multicolumn{2}{|l|}{ Duration of composting manure before use (days) } \\
\hline 30 & 69.6 \\
\hline 60 & 5.9 \\
\hline 90 & 6.9 \\
\hline 120 & 4.9 \\
\hline 150 & 1.0 \\
\hline 180 & 2.9 \\
\hline 210 & 0.0 \\
\hline 240 & 0.0 \\
\hline 270 & 0.0 \\
\hline 300 & 0.0 \\
\hline 330 & 0.0 \\
\hline 360 & 1.0 \\
\hline \multicolumn{2}{|c|}{ Waiting period after fertilizer use before harvest (weeks) } \\
\hline 1 to 4 & 39.2 \\
\hline 5 to 8 & 48.0 \\
\hline 9 to 12 & 0.0 \\
\hline 13 to 16 & 1.0 \\
\hline 17 to 20 & 0.0 \\
\hline$>20$ & 0.0 \\
\hline \multicolumn{2}{|l|}{ Pesticides used } \\
\hline Akape (Imidacloprid) & 28.4 \\
\hline Attack (Emamectin benzoate) & 63.7 \\
\hline Bypel 1 (PrGv.Bt) & 41.2 \\
\hline Fungicide (copper hydroxide) & 6.9 \\
\hline Golan (Acetamiprid) & 20.6 \\
\hline Mectin (Abamectin) & 23.5 \\
\hline Sunhalothrin 2.5 EC (Lambda cyhalothrin) & 14.7 \\
\hline
\end{tabular}


Table 4. Cont.

\begin{tabular}{ll}
\hline \multicolumn{1}{c}{ Survey Attributes } & Percentage (\%) \\
\hline Waiting period after pesticide use before harvest (days) & \\
1 to 7 & 61.8 \\
8 to 14 & 27.4 \\
15 to 21 & 4.9 \\
22 to 28 & 1.0 \\
$>28$ & 1.0 \\
\hline
\end{tabular}

The total number of respondents was 102 .

Organic and synthetic fertilizers were used in vegetable cultivation in Accra, Ghana. Nitrogen-phosphorus-potassium (NPK) was the most commonly $(72.5 \%)$ used synthetic fertilizer in addition to ammonia or urea (Table 4). All the farmers who participated in this study, with one exception, used poultry manure $(99.0 \%)$ while $8.8 \%$ of the farmers used cow manure in cultivation. About $70.0 \%$ of the farmers used manure after 30 days or less of composting; smaller minorities used manure after $60-120 ; 150-180$ or 360 days of composting. Fertilizers were usually applied once during the growing cycle of both exotic and indigenous vegetables (Table 3). Some farmers also used manure two or three times during a growing cycle while a few farmers applied manure four times in the $B$. oleracea growing cycle.

Various pesticides were used in vegetable production to control pests and diseases. About $62.0 \%$ of the farmers harvested their vegetables 1-7 days after pesticide application (Table 4). Other farmers $(27.4 \%)$ harvested their produce 8-14 days after pesticide application. Most farmers applied pesticides about $5(20.6 \%)$ or $8(36.3 \%)$ times during the growing cycle of B. oleracea (Table 3$)$. Some farmers $(10.8 \%)$ applied pesticides about 10 times during the growing cycle of B. oleracea. Majority of the farmers applied pesticides $4(30.4 \%)$ or 7 (20.6\%) times during the L. sativa growing cycle. Pesticides were applied less often on the indigenous leafy green vegetables during a growing cycle compared to exotic leafy green vegetables. Pesticides were applied once or twice during the growing cycle of indigenous vegetables.

The farmers usually harvested the vegetables with bare hands (96.1\%) and knives (71.6\%; Table 5). After harvest, the vegetables were placed into sacks $(79.4 \%)$, baskets $(51.0 \%)$, rubber bags $(12.8 \%)$, buckets $(6.9 \%)$ or unto bare grounds $(45.1 \%)$. The farmers did not store $(99.0 \%)$ or carried out any form of processing $(100 \%)$ on the harvested leafy vegetables. Vegetables were usually harvested when the buyer was ready to pick them up. Vegetable buyers came to the farms to buy the vegetables, but a few of the farmers (3.9\%) transported the harvested vegetables to busy buyers at the buyers' cost. Vegetable sellers $(99.0 \%)$ were the main customers who bought vegetables from the farmers. Household (53.9\%), street side and small food vendors (44.1\%), and operators of hotels and restaurants $(33.3 \%)$ also bought vegetables from the farmers. The harvested vegetables were transported to various market centers, retail outlets or homes in sacks $(85.3 \%)$, baskets $(29.4 \%)$ and rubber bags $(27.4 \%)$.

Most farmers who participated in the survey disagreed that the use of polluted irrigation water can contaminate vegetables $(52.9 \%)$ or make consumers sick $(52 \%)$ while other farmers $(36.3 \%$ and $38.4 \%$, respectively) had opposing opinions (Table 6). About $46 \%$ of the farmers agreed while $41 \%$ of the farmers disagreed that chemicals or contaminants in pesticides and fertilizers can get into vegetables. Approximately $42 \%$ of the farmers agreed and $46 \%$ of the farmers disagreed that chemicals or contaminants in pesticides and fertilizers can get into the soil and surrounding waters. 
Table 5. Harvest and post-harvest practices of participating vegetable farmers in Accra, Ghana.

\begin{tabular}{|c|c|}
\hline Survey Attributes & Percentage $(\%)$ \\
\hline \multicolumn{2}{|l|}{ Vegetable harvesting tools } \\
\hline Bare hands & 96.1 \\
\hline Knives & 71.6 \\
\hline garden fork & 2.0 \\
\hline \multicolumn{2}{|l|}{ Case for vegetable harvesting } \\
\hline Bare ground & 45.1 \\
\hline Basket & 51.0 \\
\hline Sack & 79.4 \\
\hline Buckets & 6.9 \\
\hline Rubber bags & 12.8 \\
\hline \multicolumn{2}{|l|}{ Did you store harvested vegetables } \\
\hline Yes & 1.0 \\
\hline No & 99.0 \\
\hline \multicolumn{2}{|l|}{ Storage of harvested vegetables } \\
\hline Airy/open place & 1.0 \\
\hline Cold room & 0.0 \\
\hline \multicolumn{2}{|l|}{ Selling of harvested vegetables } \\
\hline Sellers come to farm and buy & 100 \\
\hline Take vegetables to sellers at the market & 3.9 \\
\hline \multicolumn{2}{|l|}{ Main Vegetable buyers } \\
\hline Street side food vendors & 44.1 \\
\hline Hotels and restaurants & 33.3 \\
\hline Households & 53.9 \\
\hline Vegetable vendors & 99.0 \\
\hline \multicolumn{2}{|l|}{ Case for vegetable transport to the market left } \\
\hline Baskets & 29.4 \\
\hline Rubber/poly bags & 27.4 \\
\hline Sacks & 85.3 \\
\hline \multicolumn{2}{|l|}{ Did you carry out any form of processing } \\
\hline Yes & 0.0 \\
\hline No & 100.0 \\
\hline \multicolumn{2}{|l|}{ Extension services } \\
\hline Receive training & 91.2 \\
\hline Training on disease and pest control & 63.7 \\
\hline Training on fertilizer use & 67.6 \\
\hline Training on pesticide use & 83.3 \\
\hline
\end{tabular}

The total number of respondents was 102 .

Table 6. General food safety knowledge of participating vegetable farmers in Accra, Ghana.

\begin{tabular}{|c|c|c|c|}
\hline \multirow{2}{*}{ Survey Attributes } & \multicolumn{3}{|c|}{ Percentage (\%) } \\
\hline & Agree & Neither agree or disagree & Disagree \\
\hline Use of polluted irrigation water can contaminate vegetables & 36.3 & 10.8 & 52.9 \\
\hline $\begin{array}{l}\text { Chemicals or contaminants in pesticides and fertilizers can get into } \\
\text { vegetables }\end{array}$ & 46.1 & 12.8 & 41.2 \\
\hline $\begin{array}{l}\text { Chemicals or contaminants in pesticides and fertilizers can get into soil } \\
\text { and surrounding waters }\end{array}$ & 42.2 & 11.8 & 46.1 \\
\hline
\end{tabular}

The total number of respondents was 102.

From our previous publication, mean Enterococcus sp. and fecal coliform counts on the sampled vegetables $(n=175)$ from farmers that participated in this study were 3.67 and $4.90 \mathrm{log}$ CFU/g [13]. According to the SUR model, survey data on vegetable production practice collected in farming areas 10,11 and 12 had an inverse relationship with the fecal coliform counts found on vegetables produced by the three farming areas ( $p \leq 0.10$; Table 7$)$. Farms operated by older farmers, farmers with no formal education, or farmers planting on current farmlands for a longer period were likely to produce 
vegetables with higher fecal coliform counts compared to the other farmers $(p \leq 0.05)$. Additionally, farmers with smaller farm size produced vegetables with higher fecal coliform counts compared to those with large farm size $(p \leq 0.10)$. B. oleracea and $S$. macrocarpon production practices were negatively associated with fecal coliform counts while $C$. olitorius production practice was positively associated with higher fecal coliform counts $(p \leq 0.10)$.

Table 7. Seemingly unrelated regression model of leafy green farming practices on fecal coliform and Enterococcus sp. counts on the vegetables in Accra, Ghana.

\begin{tabular}{|c|c|c|c|}
\hline Variables & Coefficient & Standard Error & $p$-value \\
\hline \multicolumn{4}{|l|}{ Fecal coliform counts } \\
\hline Farming area $10,11,12$ & -2.3027 & 0.6267 & 0.000 \\
\hline Age of farmer & 0.0293 & 0.0152 & 0.053 \\
\hline Farmers with no formal education & 1.5220 & 0.5008 & 0.002 \\
\hline Years of planting on current farmland & 0.0727 & 0.0325 & 0.025 \\
\hline Size of farm & -0.2387 & 0.1136 & 0.036 \\
\hline B. oleracea & -1.3903 & 0.5037 & 0.006 \\
\hline C. olitorius & 1.3576 & 0.5048 & 0.007 \\
\hline S. macrocarpon & -1.0303 & 0.5143 & 0.045 \\
\hline Quantity of NPK fertilizer applied & 0.0236 & 0.0125 & 0.059 \\
\hline Quantity of poultry manure applied & 0.0032 & 0.0009 & 0.001 \\
\hline Quantity of Golan ${ }^{\circledR}$ pesticide applied & 1.3631 & 0.8273 & 0.099 \\
\hline Quantity of Mectin ${ }^{\circledR}$ pesticide applied & -2.1544 & 0.8320 & 0.010 \\
\hline Waiting period after pesticide application before harvest & -0.1192 & 0.0358 & 0.001 \\
\hline Use of contaminated irrigation water can make consumers sick & -0.6240 & 03505 & 0.075 \\
\hline $\begin{array}{l}\text { Chemical or contaminants in pesticides and fertilizers can get into } \\
\text { vegetables }\end{array}$ & 0.6611 & 0.3368 & 0.050 \\
\hline Receive training in pesticide use & -1.7245 & 0.6249 & 0.006 \\
\hline Receive training in fertilizer use & 1.5482 & 0.4879 & 0.002 \\
\hline \multicolumn{4}{|l|}{ Enterococcus counts } \\
\hline Farming areas $4,5,6$ & 0.9932 & 0.4080 & 0.015 \\
\hline Farmers with no formal education & 0.6456 & 0.3275 & 0.049 \\
\hline Years of planting on current farmland & 0.0375 & 0.0211 & 0.076 \\
\hline Quantity of NPK fertilizer applied & -0.0129 & 0.0075 & 0.088 \\
\hline Quantity of Bypel ${ }^{\circledR}$ pesticide applied & 0.8730 & 0.2925 & 0.003 \\
\hline Quantity of Golan ${ }^{\odot}$ pesticide applied & -1.1821 & 0.5719 & 0.039 \\
\hline Use of contaminated irrigation water can contaminate vegetables & 0.4072 & 0.2236 & 0.069 \\
\hline $\begin{array}{l}\text { Chemicals or contaminants in pesticides and fertilizers can get } \\
\text { into surrounding water }\end{array}$ & -0.4814 & 0.2154 & 0.025 \\
\hline Receive training in pesticide use & -1.4100 & 0.4065 & 0.001 \\
\hline Receive training in fertilizer use & 1.2633 & 0.3199 & 0.000 \\
\hline \multicolumn{4}{|l|}{ Model statistics } \\
\hline Breusch-Pagan text of independence, $\chi^{2}$ & 13.132 & & \\
\hline $\mathrm{R}^{2}$ & 0.0003 & & \\
\hline
\end{tabular}

Farmers who used higher quantities of NPK fertilizer and poultry manure were likely to produce vegetables with high fecal coliform counts $\left(p \leq 0.10\right.$; Table 7). Use of higher quantities of Golan ${ }^{\circledR}$ pesticide or lower quantities of Mectin ${ }^{\circledR}$ pesticide was associated with high fecal coliform counts $(p \leq 0.10)$ on the vegetables. The shorter the waiting period after pesticide application before harvest of vegetables was associated with higher fecal coliform counts on sampled vegetables $(p \leq 0.10)$. Farmers who disagreed that use of polluted irrigation water can make consumers sick or agreed that chemical in pesticides and fertilizers can get into vegetables were likely to produce vegetables with high fecal coliform counts $(p \leq 0.10)$. Farmers who received no training in pesticide use or farmers with training in fertilizer use were likely to produce vegetables with high fecal coliform counts $(p \leq 0.10)$.

Vegetable production practices in farming areas 4,5 and 6 were positively related to Enterococcus sp. counts on vegetables $(p \leq 0.10 ;$ Table 7$)$. Farmers with no formal education or farmers who had been planting for several years on their current farmlands $(p \leq 0.10)$ were likely to produce vegetables with higher Enterococcus sp. counts. Use of lower quantities of NPK fertilizer or Golan ${ }^{\circledR}$ pesticide and 
higher quantities of Bypel ${ }^{\circledR}$ pesticide was associated with vegetables with high Enterococcus sp. counts $(p \leq 0.10)$.

Farmers who contended that the use of contaminated irrigation water can contaminate vegetables or that chemicals or contaminants in pesticides and fertilizers can get into surrounding waters were associated with production of vegetables with high Enterococcus sp. counts ( $p \leq 0.10$; Table 7). Farmers who received no training in pesticide use or farmers with training in fertilizer use were associated with production of vegetables with high Enterococcus sp. counts $(p \leq 0.10)$.

\section{Discussion}

Most vegetable farmers were male, similar to observations previously made in Accra and other West Africa cities (Table 1) [15]. This observation may be due to societal definition of gender roles that farming is a man's job because most of the farming activities such as land preparation and irrigation are done manually [16]. Majority of the farmers were between the ages of 18 and 45 years, which is representative of the working class that may have migrated to the cities to search for jobs and ended up with urban farming when they were unable to secure what they had hoped for [17]. The illiteracy rate of approximately $49 \%$ of the vegetable farmers observed in this study were comparable to the reported $48 \%$ illiteracy rate of vegetable farmers in Accra area [7].

As the capital city of Ghana, most lands in Accra are used for infrastructural development, therefore, urban vegetable farmers have difficulty in accessing land for farming. Farming usually occurs on lands belonging to governmental institutions and private developers who have not yet started construction [7] It is, therefore, not surprising that most farm sizes were less than 0.4 ha as observed in Nigeria [18].

Most of the vegetable farmers who participated in this study cultivated exotic vegetables more than indigenous vegetables (Table 2), as reported by previous studies in Ghana and other West African countries [7]. This observation can be due to the high economic returns associated with the exotic vegetables compared to the indigenous ones. Although indigenous vegetables are usually cheaper than the exotic vegetables, they are regarded as poor people's food and thus not patronized especially in urban areas [19]. Market demands, soil conditions and expertise were previously identified factors influencing the type of vegetables cultivated [7]. In the current study, crop rotation was practiced due to low soil fertility or as mechanism to control pest and disease infestation. This differs from previous report that farmers practiced crop rotation mainly due to seasonal demands [7].

Wastewaters from drains, rivers and streams were used by most of the farmers to irrigate their vegetables (Table 4). This may be due to declining availability of fresh water associated with urbanization and lack of waste treatment facilities. The use of wastewater for irrigation in urban vegetable farming has been observed in several countries including Ethiopia, South Africa, India and Pakistan [20-23]. Availability of water for irrigation and distance to the water source were more important to the farmers in this study than the cleanliness or cost of the water. This observation may be attributed to the importance of water to meet year-round vegetable cultivation. Most farmers used watering cans for irrigating the vegetables as observed in some cities in Ghana, Togo and Nigeria $[18,24,25]$.

It was observed that pesticides were applied more often on exotic vegetables (four or more times per growing cycle) than on indigenous vegetables (three or less times per growing cycle; Table 3). This may be due to the high economic returns and market demands associated with the exotic vegetables compared to the indigenous ones, as well as the comparatively high pest infestation associated with cabbage production as claimed by the farmers [7]. Almost all the farmers used poultry manure with or without synthetic fertilizers for soil fertility maintenance required for year-round vegetable farming (Table 4). This may be because poultry manure is relatively inexpensive and easily available compared to synthetic fertilizers [9]. The vegetables were harvested when the buyers were ready to pick up the produce because there were no storage or processing facilities on the vegetable farms visited in the study. This observation may be due to a lack of infrastructure and ready market for processed 
vegetables as compared to the non-processed vegetables, which can stay relatively longer without cold storage. Most of the vegetables were sold to vegetable sellers at the farm gate because the sellers wanted to avoid middlemen costs and obtain high quality vegetables for sale [9].

Majority of the farmers in this study disagreed that there is a link between irrigation water quality and vegetable safety or consumer sickness, a finding similar to reports of previous studies from Ghana, Burkina Faso and Tanzania [26-28]. However, a study reported that farmers know that the use of contaminated irrigation water was not accepted but put up defensive strategies by underestimating the risks associated with its use when talking with local authorities, media, health personnel or general public and overestimating the risks associated with its use when they see probability of receiving donations such as farm inputs or equipment [29].

Some associations were found between the demography and agricultural practices of the farmers and the microbial safety of their vegetables. It was observed that older farmers were more likely to produce vegetables with higher fecal coliform and Enterococcus sp. counts than younger farmers because older farmers may be reluctant in changing their traditional farming practices passed to them by their fathers even after being educated of the detrimental effects from use of these practices. Previous studies in Northern Ghana and Nepal observed older farmers were less likely to adopt new practices to improve their farming activities compared to younger ones because of lack of interest in long term investment, especially if no children are expected to take over the farms [30,31].

A significant relationship existed between farmers with no education and poor microbial quality (fecal coliform and Enterococcus counts) of their vegetables. Education increases the likelihood of farmers to adopt new practices because farmers can better understand the requirements and implications of these practices [31,32]. The perception of farmers has been reported to influence their farming practices [32]. This supports our observation that farmers who disagreed that the use of polluted irrigation water can make consumers sick were more likely to produce vegetables with high microbial counts because they do not perceive the danger.

Raw manure may contain various microorganisms and application of inappropriately composted manure on farmland can increase microbial populations in the soil. Continual application of inappropriately composted manure on the same piece of land for years increases microbial populations in the soil and may subsequently contaminate the vegetables cultivated on it [33-35]. It is, therefore, not surprising there was a likelihood that farmers cultivating the same land for several years would produce vegetables with high fecal coliform and Enterococcus counts.

Agricultural extension services provide support, scientific research-based information and skills to solve problems encountered by farmers to improve their productivity and income [36]. Although extension services were provided to most of the vegetable farmers who participated in this study, it was observed that farmers who received training on fertilizer use were likely to produce vegetables with higher fecal coliform and Enterococcus counts. This indicated that farmers may not have adopted what they learned from the extension agents, or knowledge transfer process was inadequate [37].

\section{Conclusions}

Contaminated irrigation water and incompletely composted manure were used in vegetable cultivation in Accra, Ghana. The educational level and perceptions of farmers were likely to influence the production of microbiologically safer (with low fecal coliform and Enterococcus sp. counts) vegetables. This study emphasizes the need for several radical changes in production practices of Ghanaian urban vegetable farmers. Production of vegetables with clean irrigation water and properly composted manure should be encouraged. Harvested vegetables should be stored under refrigerated conditions. Vegetable producers should be educated on how to produce safer food and maintain their quality.

Author Contributions: Conceptualization: J.K.Q. and J.C.; Methodology: J.K.Q., C.L.E., A.P.-H.K., F.K.S. and J.C.; Data collection: J.K.Q., A.P.-H.K., and F.K.S.; Formal analysis: C.L.E. and J.K.Q.; Supervision: J.C. and C.L.E.; 
Funding acquisition: J.K.Q. and J.C.; Writing - original draft preparation: J.K.Q.; Writing - review and editing: J.C. All authors have read and agreed to the published version of the manuscript.

Funding: This research was funded by the Schlumberger Foundation under its Faculty for the Future Program.

Acknowledgments: The authors wish to thank the Schlumberger Foundation for supporting this research project, and to thank all the vegetable farmers that participated in the study, staff and service personnel in the Department of Nutrition and Food Science at University of Ghana, Legon, especially Grace Nmai, Jonas Otoo and Richard Otwey for their assistance during data collection.

Conflicts of Interest: The authors declare no conflict of interest. The funders had no role in the design, execution, and report of the study.

\section{References}

1. Food and Agriculture Organisation. Urban and Peri-Urban Agriculture. Available online: http://www.fao. org/unfao/bodies/COAG/COAG15/x0076e.htm\#1 (accessed on 29 January 2019).

2. Resource Centre for Urban Agriculture and Food security. Gender in urban agriculture: An introduction. In Women Feeding Cities-Mainstreaming Gender in Urban Agriculture and Food Security; Hovorka, A., Zeeuw, H., Njenga, A., Eds.; Practical Action Publishing: Rugby, UK, 2009; pp. 1-32.

3. Food and Agriculture Organisation. Feeding the Cities, the Role of Urban Agriculture. Available online: http://www.fao.org/docrep/x0262e/x0262e22.htm (accessed on 30 January 2019).

4. Food and Agriculture Organisation. Growing Greener Cities in Latin America and the Caribbean. Available online: http://www.fao.org/3/a-i3696e.pdf (accessed on 2 February 2019).

5. McEldowney, J. Urban Agriculture in Europe: Patterns, Challenges and Policies; PE 614.641; European Parliamentary Research Service: Brussels, Belgium, 2017.

6. Oberholtzer, L.; Dimitri, C.; Pressman, A.A. Urban agriculture in the United States: Characteristics, challenges, and technical assistance needs. J. Ext. 2014, 52, 6FEA1.

7. Danso, G.; Drechsel, P.; Obuobie, E.; Forkuor, G.; Kranjac-Berisavljevic, G. Urban vegetable farming sites, crops and cropping practices. In Irrigated Urban Vegetable Production in Ghana: Characteristics, Benefits and Risk Mitigation; Drechsel, P., Keraita, B., Eds.; International Water Management Institute: Colombo, Sri Lanka, 2014; pp. 12-23.

8. Drechsel, P.; Adam-Bradford, A.; Raschid-Sally, L. Irrigated urban vegetable production in Ghana. In Irrigated Urban Vegetable Production in Ghana: Characteristics, Benefits and Risk Mitigation; Drechsel, P., Keraita, B., Eds.; International Water Management Institute: Colombo, Sri Lanka, 2014; pp. 2-4.

9. Amoah, P.; Drechsel, P.; Abaidoo, R.C.; Henseler, M. Irrigated urban vegetable production in Ghana: Microbiological contamination in farms and markets and associated consumer risk groups. J. Water Health 2007, 5, 455-466. [CrossRef] [PubMed]

10. Adetunde, L.; Sackey, I.; Dombirl, D.; Mariama, Z. Potential links between irrigation water microbiological quality and fresh vegetables quality in Upper East region of Ghana subsistence farming. ARRB 2015, 6, 347-354. [CrossRef]

11. Amoah, P.; Drechsel, P.; Abaidoo, R.C.; Ntow, W.J. Pesticide and pathogen contamination of vegetables in Ghana's urban markets. Arch. Environ. Con. Tox. 2006, 50, 1-6. [CrossRef]

12. Cobbina, S.J.; Kotochi, M.C.; Korese, J.K.; Akrong, M.O. Microbial contamination in vegetables at the farm gate due to irrigation with wastewater in the Tamale metropolis of Northern Ghana. J. Environ. Prot. 2013, 7, 676-682. [CrossRef]

13. Quansah, J.K.; Kunadu, A.P.H.; Saalia, F.K.; Díaz-Perez, J.C.; Chen, J. Microbial quality of leafy green vegetables grown or sold in Accra metropolis, Ghana. Food Control 2018, 86, 302-303. [CrossRef]

14. Greene, W.H. Econometric Analysis; Prentice Hall, Inc.: Upper Saddle River, NJ, USA, 2003; pp. $340-362$.

15. Drechsel, P.; Graefe, S.; Sonou, M.; Cofie, O.O. Informal Irrigation in Urban West Africa: An Overview; International Water Management Institute: Colombo, Sri Lanka, 2006.

16. Hope, L.; Cofie, O.; Keraita, B.; Drechsel, P. Gender and urban agriculture: The case of Accra, Ghana. In Women Feeding Cities-Mainstreaming Gender in Urban Agriculture and Food Security; Hovorka, A., de Zeeuw, H., Njenga, M., Eds.; Practical Action Publishing: Rugby, UK, 2009; pp. 35-50. 
17. Obuobie, E.; Hope, L. Characteristics of urban vegetable farmers and gender issues. In Irrigated Urban Vegetable Production in Ghana Characteristics, Benefits and Risk Mitigation; Drechsel, P., Keraita, B., Eds.; International Water Management Institute: Colombo, Sri Lanka, 2014; pp. 28-37.

18. Ojo, O.D.; Connaughton, M.; Kintomo, A.A.; Olajide-Taiwo, L.O.; Afolayan, S.O. Assessment of irrigation systems for dry season vegetable production in urban and peri-urban zones of Ibadan and Lagos, Southwestern Nigeria. Afr. J. Agric. Res. 2011, 6, 236-243. [CrossRef]

19. Darkwa, S.; Darkwa, A.A. The use of indigenous green leafy vegetables in the preparation of Ghanaian dishes. J. Food Process. Technol. 2013, 4, 12.

20. Woldetsadik, D.; Drechsel, P.; Keraita, B.; Itanna, F.; Erko, B.; Gebrekidan, H. Microbiological quality of lettuce (Lactuca sativa) irrigated with wastewater in Addis Ababa, Ethiopia and effect of green salads washing methods. Int. J. Food Contam. 2017, 4, 1-9. [CrossRef]

21. Gumbo, J.R.; Malaka, E.M.; Odiyo, J.O.; Nare, L. The health implications of wastewater reuse in vegetable irrigation: A case study from Malamulele, South Africa. Int. J. Environ. Health Res. 2010, 20, 201-211. [CrossRef]

22. Yadav, K.K.; Singh, P.K.; Purohit, R.C. Impacts of Wastewater Reuse on Peri-Urban Agriculture: Case Study in Udaipur City, India. In Balanced Urban Development: Options and Strategies for Liveable Cities; Maheshwari, B., Singh, V.P., Thoradeniya, B., Eds.; Springer Nature: Cham, Switzerland, 2016; pp. 329-339.

23. Ensink, J.H.J.; Mahmood, T.; Dalsgaard, A. Wastewater-irrigated vegetables: Market handling versus irrigation water quality. Trop. Med. Int. Heal. 2007, 12, 2-7. [CrossRef] [PubMed]

24. Keraita, B.; Danso, G.; Drechsel, P. Urban irrigation methods and practices in Ghana and Togo. Urban Agric. Mag. 2003, 200, 6-7.

25. Keraita, B.; Konradsen, F.; Drechsel, P.; Abaidoo, R.C. Effect of low-cost irrigation methods on microbial contamination of lettuce irrigated with untreated wastewater. Trop. Med. Int. Heal. 2007, 12, 15-22. [CrossRef] [PubMed]

26. Henseler, M.; Amoah, P. Marketing channels for irrigated exotic vegetables. In Irrigated Urban Vegetable Production in Ghana Characteristics, Benefits and Risk Mitigation; Drechsel, P., Keraita, B., Eds.; International Water Management Institute: Colombo, Sri Lanka, 2014; pp. 51-61.

27. Ouedraogo, B. Perceptions of Ouagadougou market gardeners on water, hygiene and disease. Urban Agric. Mag. 2002, 8, 24-25.

28. Owusu, V.; Bakang, J.E.A.; Abaidoo, R.C.; Kinane, M.L. Perception on untreated wastewater irrigation for vegetable production in Ghana. Environ. Dev. Sustain. 2012, 14, 135-150. [CrossRef]

29. Mayilla, W.; Keraita, B.; Ngowi, H.; Konradsen, F.; Magayane, F. Perceptions of using low-quality irrigation water in vegetable production in Morogoro, Tanzania. Environ. Dev. Sustain. 2017, 19, 165-183. [CrossRef]

30. Keraita, B.; Drechsel, P.; Konradsen, F. Perceptions of farmers on health risks and risk reduction measures in wastewater-irrigated urban vegetable farming in Ghana. J. Risk Res. 2008, 11, 1047-1061. [CrossRef]

31. Udimal, T.B.; Jincai, Z.; Mensah, O.S.; Caesar, A.E. Factors influencing the agricultural technology adoption: The case of improved rice varieties (Nerica) in the Northern region, Ghana. JEDS 2017, 8, 137-148.

32. Ghimire, R.; Huang, W.C. Adoption pattern and welfare impact of agricultural technology: Empirical evidence from rice farmers in Nepal. J. South Asian Dev. 2016, 11, 113-137. [CrossRef]

33. Waller, B.E.; Hoy, C.W.; Henderson, J.L.; Stinner, B.; Welty, C. Matching innovations with potential users, a case study of potato IPM practices. Agric. Ecosyst. Environ. 1998, 70, 203-215. [CrossRef]

34. Atidégla, S.C.; Huat, J.; Agbossou, E.K.; Saint-Macary, H.; Glèlè Kakai, R. Vegetable contamination by the fecal bacteria of poultry manure: Case study of gardening sites in southern Benin. Int. J. Food Sci. 2016, 2016, 1-8. [CrossRef] [PubMed]

35. de Freitas, J.R.; Schoenau, J.J.; Boyetchko, S.M.; Cyrenne, S.A. Soil microbial populations, community composition, and activity as affected by repeated applications of hog and cattle manure in eastern Saskatchewan. Can. J. Microbiol. 2003, 49, 538-548. [CrossRef] [PubMed] 
36. Venglovsky, J.; Sasakova, N.; Placha, I. Pathogens and antibiotic residues in animal manures and hygienic and ecological risks related to subsequent land application. Bioresour. Technol. 2009, 100, 5386-5391. [CrossRef] [PubMed]

37. The World Bank. 2008 World Development Report, Agriculture for Development. Available online: https://siteresources.worldbank.org/INTWDRS/Resources/477365-1327599046334/8394679-1327614067045/ WDROver2008-ENG.pdf. (accessed on 25 November 2019).

(c) ( 